\title{
A Interpolação da Lei de Mitscherlich e a Análise da Variancia em Experiências de Adubação
}

\author{
FREDERICO PIMENTEL GOMES
}

Escola Superior de Agricultura "Luiz de Queiroz"

Universidade de S. Paulo - Brasil

Tradução do trabalho "The Interpolation of Mitscherlich's First Approach Law and the Analysis of Variance in Experiments with Fertilizers", apresentado e aprovado no "VIII e Congrès International des Industries Agricoles", realizado em Bruxelas, de 9 a 15 de julho de 1950 .

INDICE

1 - Introdução. . . . . . . . . . . . . . . . . . . . . . . . . . . 186

2 - $O$ cálculo de $\mathbf{A}, \mathbf{b}$, c pelo método dos quadrados mínimos .. 187

3 - A aplicação da lei de Mitscherlich na análise da variância .. 189

4 - Exemplo de análise. . . . . . . . . . . . . . . . . . . . . 190

5 - A aplicabilidade da lei . . . . . . . . . . . . . . . . . . . . . . . 192

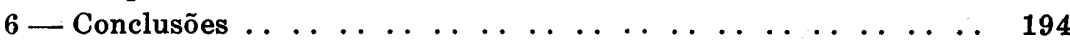

7 — Nota . . . . . . . . . . . . . . . . . . . . . . . . . . . . 194

1 - Introduction . . . . . . . . . . . . . . . . . . . . . . . . 195

2 - The computation of A, b, c by the method of least squares 196

3 - The application of Mitscherlich's law in the analysis of vari-

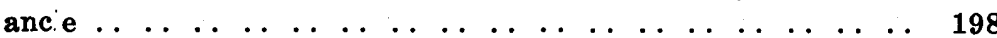

4 -_ Example of analyses . .

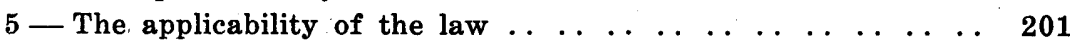

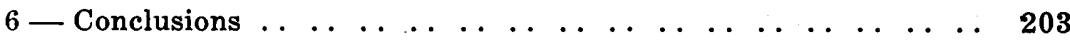

7 — Note . . . . .

8 - Bibliografia (References) $\ldots \ldots \ldots \ldots \ldots \ldots$ 


\section{1 - INTRODUÇÃO}

Este trabalho trata da estimação dos parâmetros da lei de Mitscherlich e do seu uso na análise da variância em experiências de adubação. Hoje é evidente que a interpolação e o uso da equação

$$
y=A[1-10-c(x+b)],
$$

tal como foram feitos por Mitscherlich nos seus trabalhos clásicos, e por Rippel e outros posteriormente, repousam sôbre estimativas empíricas dos parâmeros e sôbre outras suposições simplificadoras não justificáveis, como demonstraram Kletochkowsky e Shelesnow (2).

Pensamos que o melhor método de interpolação e utilização da lei de Mitscherlich deveria seguir as seguintes regras :

I - Calcular os parâmetros A, b, c, pelo método da máxima verossimilhança, que é equivalente ao dos quadrados mínimos quando a variável casual tem distribuição normal (1, p. 59).

II - Calcular os valores esperados $\hat{y}$ de y.

III - Calcular uma estimativa para a variância com o auxílio dos valores observados e dos esperados. Esta estimativa não deve diferir estatìsticamente da variância obtida do resíduo pelos métodos comuns de análise.

IV - Obter estimativas das variâncias dos parâmetros.

V - Repetir as experiências e cálculos sob condições diferentes para estudar o comportamento dos parâmetros e para verificar em que casos a aplicação da lei é justificada.

A primeira tentativa para estabelecer os métodos para interpolação e uso verdadeiramente científicos da lei de Mitscherlich foi feita por Kletschkowsky e Shelesnow (2). Êstes autores obtinham estimativas grosseiras para $A$ e $c$ e as melhoravam, a seguir, pelo método dos quadrados mínimos. Calcularam, também, as variâncías de $A$ e de c. Um valor constante conhecido era atribuído a $b$, o que é possível em experiências em vaso com areia lavada como as usadas por êles.

Êste método, porém, não é apropriado a experiências com solos. Pimentel Gomes e Malavolta (4), em 1949, foram, provàvelmente, os primeiros a usar a interpolação da lei de Mitscherlich pelo método dos quadrados mínimos em experiências com solos em vez de areia. Posteriormente Pimentel Gomes. (5) 
combinou o uso da lei de Mitscherlich à análise da variância. Mas a problema da estimação das variâncias dos parâmetros $A$, $b, c$ continuava sem solução, exceto para experiências com areia.

W. L. Stevens (não publicado) deu outra solução, e calculou as variâncias dos parâmetros tomando a equação sob a forma

$$
\mathrm{y}=\alpha+\beta \varrho^{\mathrm{x}} .
$$

Sua solução é bastante semelhante à de Kletschkowsky e Shelesnow. Nos casos em que a lei de Mitscherlich é bem apropriada, o método de Stevens dá resultados satisfatórios. Mas só nesses, pois Stevens supõe "a priori" a aplicabilidade da lei de Mitscherlich, buscando uma estimativa grosseira para $Q$, a ser melhorada, pelo métodos dos quadrados mínimos, sem procurar verificar a possibilidade e conveniência de aplicação da lei.

\section{2 - O CALCULO DE $A, b$, c PELO MétOdo DOS QUADRADOS MINIMOS}

Quando, numa experiência de adubação, xi e yi $(i=1,2$, $\ldots, n$ ) são, respectivamente, as doses de fertilizante e as colheitas por parcela, o método dos quadrados mínimos conduz às equações $(4$, pp. $6-7)$ :

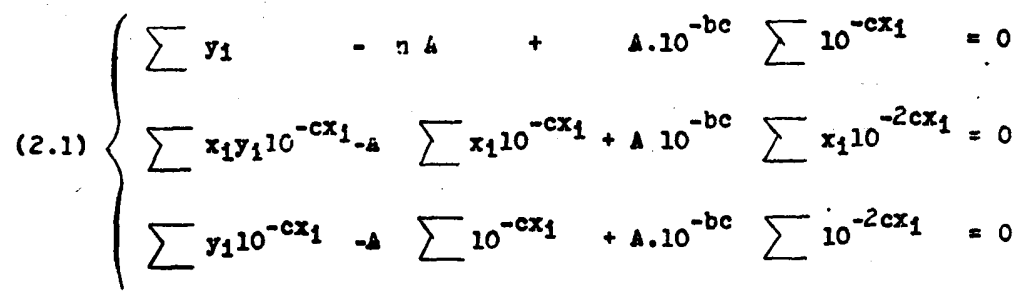

A eliminação de $\mathrm{A}$ e $\mathrm{b}$ dá a equação

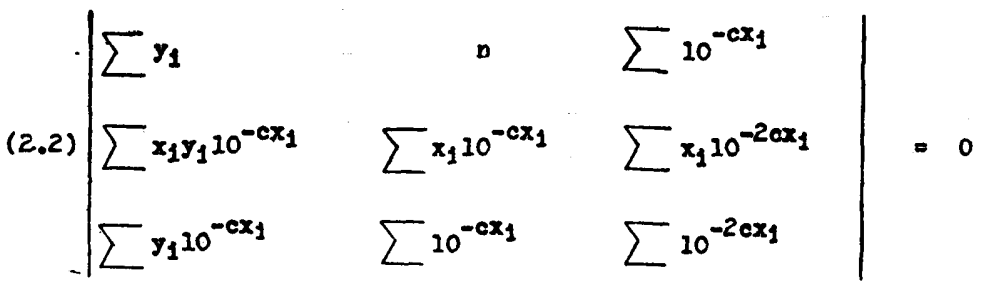


Esta equação permite calcular o valor de c. O melhor meio de resolvê-la consiste em tomar

$$
\mathrm{xi}=\mathrm{mi} \mathrm{q},(\mathrm{i}=1,2,1 \ldots, \mathrm{n}),
$$

onde mi é inteiro, e fixar

$$
\mathrm{z}=10-\mathrm{cq}, \quad \therefore 10-\mathrm{cxi}=\mathrm{zmi}^{\mathrm{m}}
$$

Substituindo êste último valor em (2.2), obtemos uma equação algébrica; que pode ser resolvida pelos métodos usuais de aproximação. A única raíz que interessa é a que está entre zero e um, pois sendo c e q necessàriamente positivos, devemos ter

$$
0<z<1 .
$$

Calculado c, fácil é determinar $\mathrm{A}$ e $\mathrm{b}$ com o auxílio das equações $(2,1)$.

Se preferíssemos a forma usada por Stevens, um processo semelhante poderia ser aplicado. Com efeito, se escrevermos a equação de Mitscherlich sob a forma

$$
y=\alpha+\beta \varrho^{\mathrm{x}}
$$

teremos evidentemente

$\alpha=\mathrm{A}, \quad \beta=-\mathrm{A} .10-\mathrm{bc}, \quad \varrho=10-\mathrm{c}$,

e, como se vê fàcilmente, as equações (2.1) e (2.2) se transformarão nas seguintes :

$$
\begin{aligned}
& \text { (2.3) }\left\{\begin{array}{lll}
\sum y_{1} & -n \alpha & -\beta \sum \rho^{x_{1}}=0, \\
\sum x_{1} y_{1} \rho x_{1} & -\alpha \sum x_{1} \rho^{x_{1}} & -\beta \sum x_{1} \rho^{2 x_{1}}=0, \\
\sum y_{1} \rho x_{1} & -\alpha \sum x_{1} & -\beta \sum \rho^{2 x_{1}}=0,
\end{array}\right. \\
& \text { (2.4) }\left|\begin{array}{lll}
\sum y_{1} & n & \sum \rho^{x_{1}} \\
\sum x_{1} y_{1} \rho^{x_{1}} & \sum x_{1} \rho^{x_{1}} & \sum x_{1} \rho^{2 x_{1}} \\
\sum y_{1} \rho^{x_{1}} & \sum \rho^{x_{1}} & \sum \rho^{2 x_{1}}
\end{array}\right|=0 .
\end{aligned}
$$


Suponhamos ainda

$$
\mathrm{xi}=\mathrm{mi} \mathrm{q}, \quad \mathrm{z}=\varrho^{\mathrm{q}}
$$

logo $Q^{\mathrm{xi}}=\mathrm{z}^{\mathrm{mi}} \quad$ e (2.4) nos dá a equação algébrica

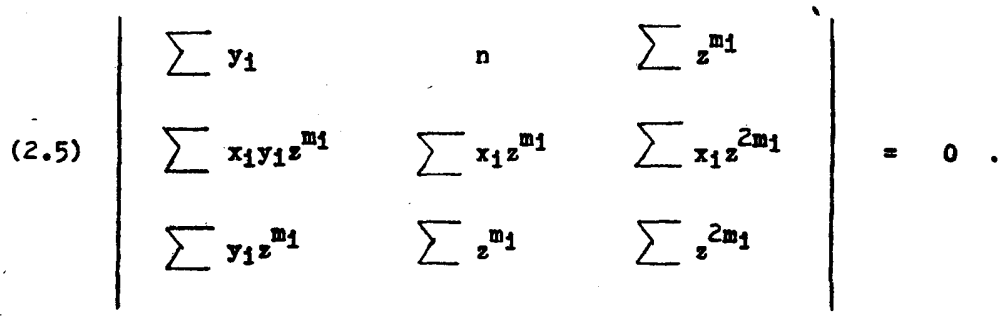

Os valores dos têrmos da segunda e terceira colunas de (2.5) podem ser calculados e tabuladas, para valores de $z$ entre zero e um, afim de reduzir o trabalho no caso de experimentos que obedeçam o plano experimental análogo.

Por outro lado, podemos desenvolver o determinante e obter uma equação na forma polinomial corrente:

$$
\underset{0}{a} z^{m}-a_{1} z^{m-1}+\ldots+a_{m-1} z+a_{m}=0 \text {. }
$$

Um raíz conhecida da equação (2. 6) é $z=1$, o que nos dá ưma boa verificação para o cálculo de (2.6). De fato, isto nos mostra que devemos ter forçosamente

$$
\underset{0}{a}+a_{1}+\ldots+\underset{m-1}{a}+a_{m}=0 .
$$

Se houver uma raíz $\mathrm{z}$ entre zero e um, uma primeira verificação da aplicabilidade da lei de Mitscherlich está feita.

Conhecendo esta raíz, é fácil calcular $\varrho, \alpha$ e $\beta$ e, fina'. mente, os valores esperados $\hat{y} \mathbf{i}$ de $\mathrm{y}$.

\section{3 - A APLICAÇÃO DA LEI DE MITSCHERLICH NA ANALISE DA VARIÂNCIA}

Suponhamos agora uma experiência da adubação com um fertilizante foi feita com $m$ níveis distintos e $r$ repetições. Usaremos as notações : $\overline{\mathrm{y}}$ para a média de tôdas as $\mathrm{n}=\mathrm{mr}$ parce- 
las, $\overline{y j}(\mathrm{j}=1,2, \ldots, \mathrm{m})$ para a média em cada nível, e $\hat{y} \mathrm{j}$ para o valor esperado em cada nível, calculado pela lei de Mitscherlich como acabamos de ver.

Quando a lei de Mitscherlich é aplicada por meio do método dos quadrados mínimos, é fácil mostrar (5) que

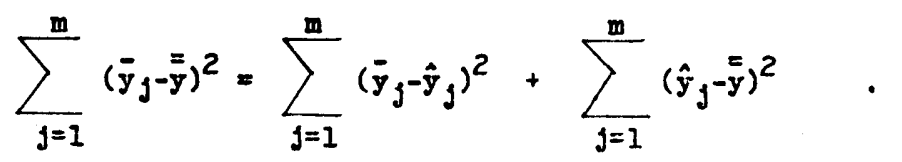

O primeiro têrmo do segundo membro de (3.1) nos dá uma nova estimativa da variância e, portanto, não deve diferir estatìsticamente da estimativa obtida do resíduo. $O$ segundo têrmo do segundo membro de (3.1) fornece uma estimativa da variância atribuida aos tratamentos, devido à regressão pela lei de Mitscherlich, com grau de liberdade igual a m-3. Esta estimativa deve ser estatìsticamente diferente da variância obtida a partir do resíduo, pois só assim poderemos assegurar a existência de efeito significativo das diversas doses de fertilizante.

\section{4 - EXEMPLO DE ANALISE}

Em uma experiência de adubação de trígo feita em Ponta Grossa, Paraná, pelo Ministério de Agricultura do Brasil, aplicou-se cal hidratada nas doses de $0,2,4,6$ e 8 toneladas por hectare, a serem indicadas, respectivamente, por A, B, C, D, E. Usou-se um quadrado latino de $5 \times 5$. A calagem foi feita em 1940 e o trigo foi cultivado nas mesmas parcelas durante vários anos. A seguinte adubação foi aplicada anualmente a tôdas as parcelas :

\section{$\mathrm{NaNO} 3$ \\ Superfosfato $\mathrm{K} 2 \mathrm{SO} 4$}

$$
\begin{array}{r}
100 \mathrm{~kg} / \mathrm{ha}, \\
350 \mathrm{~kg} / \mathrm{ha}, \\
80 \mathrm{~kg} / \mathrm{ha} .
\end{array}
$$

Os dados obtidos na colheita de 1942 são dados abaixo em $\mathrm{kg} / \mathrm{ha}$.

\begin{tabular}{|c|c|c|c|c|}
\hline $1580 \mathrm{D}$ & $1300 \mathrm{E}$ & $1010 \mathrm{~A}$ & $1540 \mathrm{C}$ & $1480 \mathrm{~B}$ \\
\hline $1510 \mathrm{E}$ & $1280 \mathrm{~B}$ & $1400 \mathrm{C}$ & $1050 \mathrm{~A}$ & $1520 \mathrm{D}$ \\
\hline $1010 \mathrm{~A}$ & $1380 \mathrm{C}$ & $1440 \mathrm{P}$ & $1660 \mathrm{D}$ & $1790 \mathrm{E}$ \\
\hline $1410 \mathrm{C}$ & $1320 \mathrm{D}$ & $1270 \mathrm{E}$ & $1410 \mathrm{~B}$ & $1070 \mathrm{~A}$ \\
\hline $1320 \mathrm{~B}$ & $780 \mathrm{~A}$ & $1350 \mathrm{D}$ & $1450 \mathrm{E}$ & $1560 \mathrm{C}$ \\
\hline
\end{tabular}


A equação em $\mathbf{z}$ obtida foi

$630 z^{10}+472 z^{9}+708 z^{8}-5632 z^{7}+3602 z^{6}-2280 z^{5}+$

$+4158 z^{4}-1348 z^{3}+972 z^{2}-1532 z+250=0$.

A única raíz existente entre zero e um é $z=0,1815$. Como temos

$$
z=10-2 c \text {, }
$$

$$
c=\frac{1}{2} \operatorname{colog} 0,1815=0,37056 \text {. }
$$

Conhecido êste valor de $c$, fácilmente calculamos $A$ e $b$ e obtemos a equação

$$
\begin{aligned}
& \mathrm{y}=1476,2[1-10-0,37056(\mathrm{x}+1,2836)], \\
& \mathrm{ou} \\
& \mathrm{y}=1476,2-493,7(0,42603) \mathrm{x} .
\end{aligned}
$$

\begin{tabular}{|c|c|c|c|}
\hline $\begin{array}{l}\text { Causa de } \\
\text { variação }\end{array}$ & $\begin{array}{c}\text { Grau de } \\
\text { liberdade }\end{array}$ & $\begin{array}{l}\text { Soma dos } \\
\text { quadrados }\end{array}$ & $\begin{array}{l}\text { Quadrado } \\
\text { médio }\end{array}$ \\
\hline $\begin{array}{l}\text { Linhas } \\
\text { Colunas } \\
\text { Tratamentos } \\
\text { Resíduo }\end{array}$ & $\begin{array}{r}4 \\
4 \\
4 \\
12\end{array}$ & $\begin{array}{rl}91 & 936 \\
227 & 096 \\
891 & 256 \\
51 & 928\end{array}$ & $\begin{array}{rl}22 & 984 * \\
56 & 774 * * \\
222 & 814 \\
4 & * * \\
4327\end{array}$ \\
\hline Total & 24 & 1262216 & \\
\hline
\end{tabular}

A análise comum da variância nos dá :

Com a equação (4.1) ou (4.2) podemos calcular os valores esperados $\hat{y j}$ de y, que são dados abaixo.

\begin{tabular}{lccccc}
\hline & A & B & C & D & E \\
\hline $\begin{array}{l}\text { Valores } \\
\text { esperados }\end{array}$ & 982,5 & 1386,6 & 1459,9 & 1473,2 & 1475,4 \\
\hline $\begin{array}{l}\text { Média dos } \\
\text { valores } \\
\text { observados }\end{array}$ & 984,0 & 1386,0 & 1458,0 & 1486,0 & 1464,0 \\
\hline
\end{tabular}


Agora podemos aplicar (3.1) e repartir a soma dos quadrados atribuída aos tratamentos em duas porções, como mostramos a seguir.

\begin{tabular}{c|c|c|c}
\hline $\begin{array}{c}\text { Causa de } \\
\text { variação }\end{array}$ & $\begin{array}{c}\text { Grau de } \\
\text { liberdade }\end{array}$ & $\begin{array}{c}\text { Soma dos } \\
\text { quadrados }\end{array}$ & $\begin{array}{c}\text { Quadrado } \\
\text { médio }\end{array}$ \\
\hline $\begin{array}{l}\text { Regressão pela } \\
\text { lei de }\end{array}$ & & & \\
\begin{tabular}{l} 
Mitscherlich \\
\hline $\begin{array}{c}\text { Desvios da } \\
\text { regressão }\end{array}$
\end{tabular} & 2 & 889756 & $444878 * *$ \\
\hline
\end{tabular}

Os desvios da regressão fornecem nova estimativa para a variância residual. Esta estimativa não difere da que foi obtida anteriormente. Portanto, está provada a aplicabilidade da lei neste caso.

As variâncias de $\alpha, \beta$ e $\varrho$ podem ser calculadas pelo método de Stevens. Elas são, respectivamente,

$$
\begin{gathered}
\mathrm{s}^{2}=2029, \mathrm{~s}^{2}=6227, \mathrm{~s}^{2}=0,02668 . \\
\varrho \\
5-\mathrm{A} \text { APLICABILIDADE DA LEI }
\end{gathered}
$$

Ha muita controvérsia sôbre a aplicabilidade em geral da lei de Mitscherlich. E' inegável que em muitos casos a lei não pode ser aplicada e é por isso que julgamos necessário verificar a aplicabilidade em cada caso investigado.

Em muitos casos em que a primeira aproximação de Mitscherlich não é conveniente, a segunda aproximação pode ser aplicada. Mas mesmo em alguns casos em que não há efeito nocivo do fertilizante, ambas as fórmulas não são adequadas.

Mesmo em casos em que as colheitas seguem, fundamentalmente, a primeira aproximação da lei de Mitscherlich, desvios de acaso dos valores esperados podem causar grande êrro experimental e conduzir à impossibilidade de aplicação da lei aos dados. Esta conclusão pode ser demonstrada matemáticamente.

Suponhamos, por exemplo, uma experiência com três doses de fertilizante $x 1, x 2, x 3$ sendo $x 2-x 1=x 3-x 2$. Se a lei de 
Mitscherlich se verificar devemos ter para $i=1,2,3$ os valores esperados

$$
\hat{y} \mathrm{i}=\mathrm{A}[1-10-\mathrm{c}(\mathrm{xi}+\mathrm{h})]
$$

Mas, devido ao êrro experimental, temos, em lugar de $\hat{\mathrm{y}}$, uma variável casual com média $\hat{y} i$ e variância $\sigma^{2}$.

No caso que estamos discutindo, devemos ter (3,pp. 11-13), sendo yi $(i=1,2,3)$ as médias observadas das $r$ repetições nos três níveis considerados,

$$
\begin{aligned}
& \overline{\mathrm{y}} 1<\overline{\mathrm{y}} 2<\overline{\mathrm{y}} 3, \\
& \overline{\mathrm{y}} 3<2 \mathrm{y} 2-\mathrm{y} 1 .
\end{aligned}
$$

Devido a (5.1), a probabilidade de que seja possível a aplicação da lei aos dados observados será

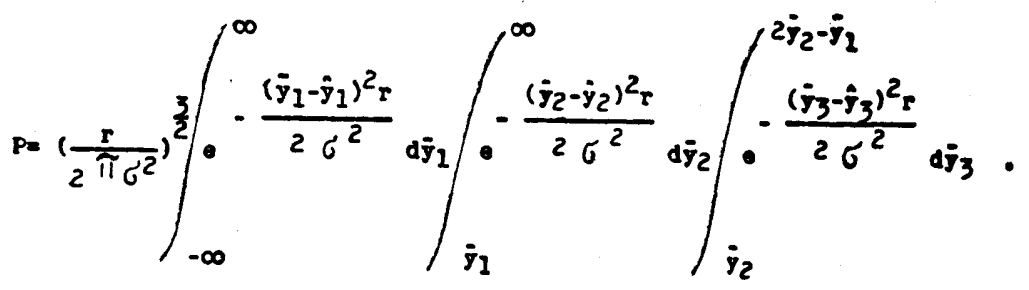

Demonstra-se fàcilmente que temos $\mathrm{P}<1$, isto é, que existe a possibilidade de inaplicabilidade da lei mesmo quando ela é essencialmente correta. Exceto em casos raros em que o êrro experimental $\sigma$ é extremamente grande, ou a diferença $\mathrm{x} 2-\mathrm{x} 1=\mathrm{x} 3-\mathrm{x} 2$ excessivamente pequena, $\mathrm{P}$ não pode ter valor próximo de zero. Para qualquer valor entre zero e um, por exemplo $\mathrm{P}=0,8$, isto significa que a lei pode ser aplicada em $80 \%$ dos casos examinados. Esta possibilidade pode ser melhorada pelo uso de delineamentos apropriados, diminuindo, assim, o êrro experimental, e pela fixação de uma diferença $\mathrm{x} 2-\mathrm{x} 1=\mathrm{x} 3-\mathrm{x} 2$ suficientemente grande para obter um valor de $\mathrm{P}$ tão próximo de 1 quanto possível, mas não tão grande que apareçam efeitos nocivos dos fertilizantes. 


\section{6 - CONCLUSÕES}

Estimativas eficientes dos parâmetros da primeira aproximação da lei de Mitscherlich podem ser obtidas pelo método dos quadrados mínimos sem cálculos excessivamente laboriosos. Algumas vêzes os cálculos indicam a impossibilidade de aplicação da lei.

A análise da variância e testes para a possibilidade e conveniência de aplicação da lei podem ser associados.

A equação de Mitscherlich pode não ser aplicável em alguns casos, mesmo quando essencialmente correta, quando a variação de acaso que afeta os dados é muito grande.

Os novos métodos apresentados dão maior importância à lei de Mitscherlich e permitem seu uso na análise da variância de certos tipos de experiências de adubação.

$O$ cálculo da variância do parâmetro $\varrho=10-c$ pelo método de Stevens dá uma sólida base ao estudo da constância de $c$ em experimentos com solos.

\section{7 - NOTA}

Somos gratos ao Professor F. G. Brieger, que corrigiu a versão inglêsa dêste trabalho, e ao Dr. Raul Edgard Kalckmann, que nos forneceu os dados experimentais. 


\section{THE INTERPOLATION OF MITSCHERLICH'S FIRST APPROACH LAW AND THE ANALYSIS OF VARIANCE IN EXPERIMENTS WITH FERTILIZERS}

\section{1 - INTRODUCTION}

The present contribution deals with the estimation of the parameters of Mitscherlich's law and its use in the analysis of variance in fertilizer experiments. It is now quite evident that the interpolation and use of the formula

$$
y=A[1-10-c(x+b)],
$$

as made by Mitscherlich in his classical studies and by Rippel and others later on, are derived mainly from empirical estimates of the parameters and further simplifying assumptions which are not justifiable, as shown by Kletschkowsky and Shelesnow (2).

We think that the best method of scientific aproach to Mitscherlich's law would be the following:

I - Compute the parameters A, b, c by the method of maximum likelihood, which is equivalent to that of least squares for cases where the stochastic variables are normally distributed $(1$, p. 59).

II - Compute the expected values $\hat{y}$ of $y$.

III - Compute an estimate for the variance with the aid of the observed and the expected values. This estimate must not be statistically different from the residual variance obtained by the usual methods of analysis of variance.

IV - Obtain estimates for the variances of the parametrs.

$\mathrm{V}$ - Repeat the experiment and calculations under different conditions in order to follow changes in the parameters and to find out in what cases the application of the law is justified.

The first attempt to establish the methods for a really scientific interpolation and use of Mitscherlich's law was made by Kletschkowsky and Shelesnow (2). These authors obtained rough estimates for $A$ and $c$, improving then these estimates by the method of least squres. They were able to compute the variances of $A$ and $c$. A constant known value was attributed to $b$, which was possible for pot experiments with clean sand, as used by the authors.

This method, however, is not suitable for experiments with soil. Pimentel-Gomes and Malavolta (4), in 1949, proba- 
bly were the first to use the interpolation of Mitscherlich's first approach law by the method of least squares for experiments with soils instead of sand. Later on Pimentel-Gomes applied Mitscherlich's function in the analysis of variance. But the problem of estimation of the variances of the parameters $A, b, c$ still remained unsolved, except for experiments with sand.

W: L. Stevens (unpublished) gave another solution, computing the variances of the parameters with the help of the function in the form

$$
\mathrm{y}=\alpha+\boldsymbol{\beta} \varrho^{\mathrm{x}} .
$$

His solution is somewhat related to that of Kletschkowsky and Shelesnow. In those cases where the use of Mitscherlich's formula is justified, Stevens' method gives satisfactory results. In fact, Stevens assumes "a priori" the applicability of Mitscherlich's law, seeking a rough aproximation for $O$ to be improved by the method of least squares, without testing the applicability.

2 - THE COMPUTATION OF $A, b$, c BY THE METHOD OF LEAST SQUARES

When in an experiment with fertilizers xi and yi $(i=1,2$, $\ldots, n)$ are respectively the amounts of fertilizer and the yields per plot, the method of least squares leads to the equations (4, pp. 6-7):

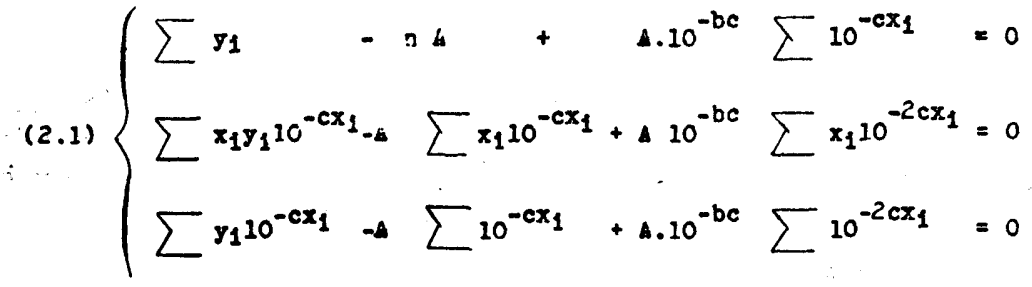

The elimination of $A$ and $b$ gives the equation.

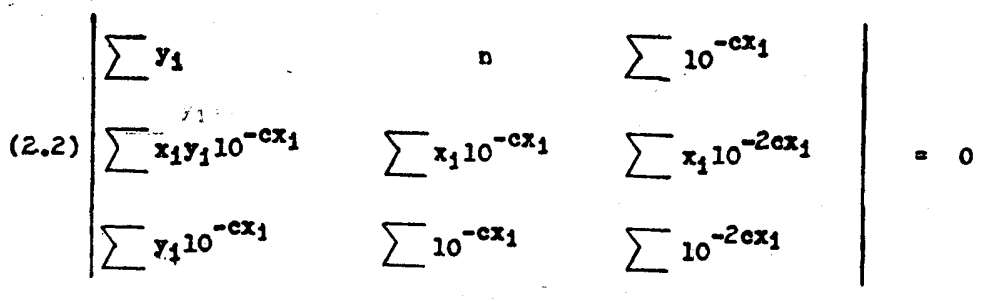


This equation gives the value of $\mathrm{c}$. The best way of solving it is to take

$$
x i=\operatorname{miq} .(i=1,2, \ldots, n),
$$

where $\mathrm{mi}$ is an integer, and let

$$
\mathrm{z}=10-\mathrm{cq}, \quad \therefore 10-\mathrm{cxi}=\mathrm{zmi} \text {. }
$$

Substituting in (2.2) we obtain an algebraic equation, which can be solved by the usual methods of aproximation. The only root which should be obtainel must lie betweem 0 and 1 , since, with $c$ and $q$ necessarily positive, we must have

$$
0<z<1 .
$$

After calculating the value of $c$, it is easy to compute $A$ and $b$ with the aid of equations (2.1).

In view of Stevens' transformation, a similar procedure may be applied. If we write Mitscherlich's formula in the form

we have evidently $\mathbf{y}=a+\beta \varrho^{\mathrm{x}}$

$a=\mathrm{A}, \quad \beta=-\mathrm{A} .10-\mathrm{bc}, \quad \varrho=10-\mathrm{c}$,

and it is easy to see that equations (2.1) and (2.2), should be written:

$$
\begin{aligned}
\text { (2.3) }\left\{\begin{array}{lll}
\sum y_{1} & -n \alpha & -\beta \sum \rho^{x_{1}}=0, \\
\sum x_{1} y_{1} \rho^{x_{1}} & -\alpha \sum x_{1} \rho^{x_{1}} & -\beta \sum x_{1} \rho^{2 x_{1}}=0, \\
\sum y_{1} \rho^{x_{1}} & -\alpha \sum p_{x_{1}} & -\beta \sum \rho^{2 x_{1}}=0,
\end{array}\right. \\
\text { (2.4) }\left|\begin{array}{lll}
\sum_{y_{1}} & \sum \rho^{x_{1}} \\
\sum x_{1} y_{1} \rho^{x_{1}} & \sum x_{1} \rho^{x_{1}} & \sum x_{1} \rho^{2 x_{1}} \\
\sum y_{1} \rho^{x_{1}} & \sum \rho^{x_{1}} & \sum \rho^{2 x_{1}}
\end{array}\right|=0 .
\end{aligned}
$$


If we put again

$$
\mathrm{xi}=\mathrm{mi}, \quad \mathrm{z}=\varrho^{\mathrm{q}}
$$

the $\mathrm{n} \quad Q^{\mathrm{xi}}=\mathrm{z}^{\mathrm{mi}}$ and (2.4) gives the algebraic equation

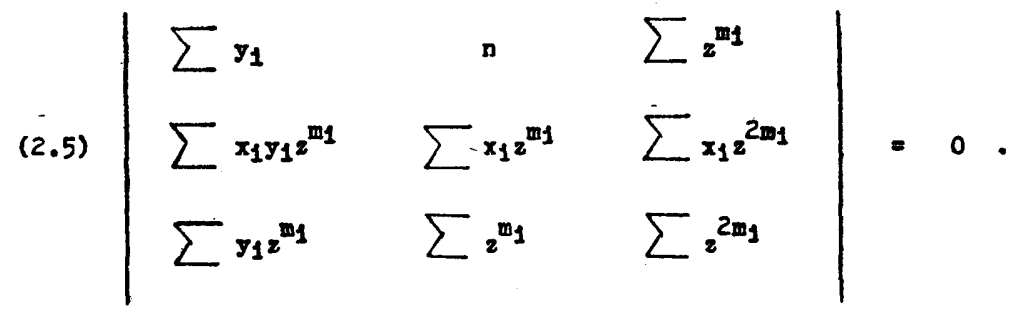

Values of the terms in the second and third columns of (2.5) may be calculated and tabulated (for values of $\mathrm{z}$ between 0 and 1) to reduce the work when dealing with comparable sets of experiments.

On the other hand, we may develop the determinant and get an equation in the usual polynomial form:

$$
\underset{0}{a z^{m}}+\underset{1}{a z^{--1}}+\ldots+a{ }_{m-1} z+a=0 .
$$

A known root of equation (2.5) is $\mathrm{z}=1$, which provides a good check for the calculation of (2.6), In fact, substituting $\mathrm{z}=1$ in (2.6) we must have

$$
a_{0}+a_{1}+\cdots+a_{m-1}+a_{m}=0 .
$$

If there is one root $\mathrm{z}$ between 0 and 1 , a first check of the applicability of Mitscherlich's law is made. Knowing this root, it easy to compute $Q, \alpha$ and $\beta$ and finally the expected values $\hat{y i}$ of $y$.

\section{3 - THE APPLICATION OF MITSCHERLICH'S LAW IN THE ANALYSIS OF VARIANCE}

Let us assume now that an experiment with a fertilizer was made with $m$ levels and $r$ replications. We shall denote by $\bar{y}$ the mean of all $n=m r$ plots, by $\bar{y} j(j=1,2, \ldots, m)$ the mean of 
each level, and by $\hat{y j}$ the expected value of each level, calculated by Mitscherlich's law as shown before.

When Mitscherlich's law is applied by means of the method of least squares it is easy to show (5) that

(3.1)

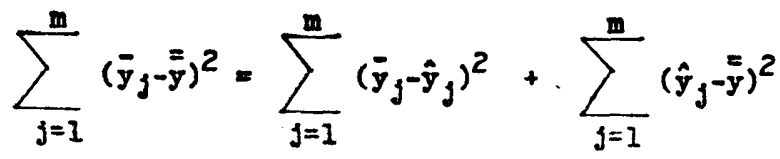

The first term on the right of (3.1) provides a new estimate of the variance and, therefore, should be not statistically different from the estimate obtained from the residual. The second term on the right of (3.1) provides an estimate of the variance attributable to treatments, as expected under Mitscherlichs's law, with degree of freedom equal to $m-3$. This estimate must be statistically different from the residual variance when the experiment was successful in showing fertilizer effects.

\section{4 - EXAMPLE OF ANALYSIS}

In an experiment on wheat made in Ponta Grossa, Paraná, by the Ministry of Agriculture of Brasil, lime in the form of $\mathrm{Ca}(\mathrm{OH}) 2$ was applied at the levels of $0,2,4,6$ and 8 metric tons per hectare, to be referred respectively by A, B, C, D, E. A 5 × 5 Latin square was used. Lime was applied in 1940 and wheat was cultivated in the same plots for several years. The following fertilizers were annually used for all plots:

\section{$\mathrm{NaNO} 3$ \\ Superfosfato \\ $\mathrm{K} 2 \mathrm{SO} 4$}

$100 \mathrm{~kg} / \mathrm{ha}$, $350 \mathrm{~kg} / \mathrm{ha}$, $80 \mathrm{~kg} / \mathrm{ha}$.

The yields obtained in 1942 are given below in $\mathrm{kg} / \mathrm{ha}$.

\begin{tabular}{|c|c|c|c|c|}
\hline $1580 \mathrm{D}$ & $1300 \mathrm{E}$ & $1010 \mathrm{~A}$ & $1540 \mathrm{C}$ & $1480 \mathrm{~B}$ \\
\hline $1510 \mathrm{E}$ & $1280 \mathrm{~B}$ & $1400 \mathrm{C}$ & $1050 \mathrm{~A}$ & $1520 \mathrm{D}$ \\
\hline $1010 \mathrm{~A}$ & $1380 \mathrm{C}$ & $1440 \mathrm{P}$ & $1660 \mathrm{D}$ & $1790 \mathrm{E}$ \\
\hline $1410 \mathrm{C}$ & $1320 \mathrm{~J}$ & $1270 \mathrm{E}$ & $1410 \mathrm{~B}$ & $1070 \mathrm{~A}$ \\
\hline $1320 \mathrm{~B}$ & $780 \mathrm{~A}$ & $1350 \mathrm{D}$ & $1450 \mathrm{E}$ & $1560 \mathrm{C}$ \\
\hline
\end{tabular}

The calculated equation in terms of $z$ was: $630 \mathrm{z}^{10}+472 \mathrm{z}^{9}+708 \mathrm{z}^{8}-5632 \mathrm{z}^{7}+3602 \mathrm{z}^{6}-2280 \mathrm{z}^{5}+$ $+4158 z^{4}-1348 z^{3}+972 z^{2}-1532 z+250=0$. 
The only root between 0 and 1 is $z=0.1815$. As

we have

$$
\mathrm{z}=10-2 \mathrm{c},
$$

$$
c=\frac{1}{2} \operatorname{colog} 01815=0.37056 \text {. }
$$

Knowing this value of $c$ we easily compute $A$ and $b$ and obtain the equation

$$
\begin{aligned}
\mathrm{y} & =1476.2[1-10-0.37056(\mathrm{x}+1.2836)], \\
\text { or } & \mathrm{y}=1476.2-493.7(0.42603) \mathrm{x} .
\end{aligned}
$$

\begin{tabular}{|c|c|c|c|}
\hline $\begin{array}{l}\text { Source of } \\
\text { variation }\end{array}$ & $\begin{array}{l}\text { Degrees of } \\
\text { freedom }\end{array}$ & $\begin{array}{l}\text { Sums of } \\
\text { squares }\end{array}$ & Mean scquare \\
\hline $\begin{array}{l}\text { Rows } \\
\text { Columns } \\
\text { Treatments } \\
\text { Residual }\end{array}$ & $\begin{array}{r}4 \\
4 \\
4 \\
12\end{array}$ & $\begin{array}{rl}91 & 936 \\
227 & 096 \\
891 & 256 \\
51 & 928\end{array}$ & $\begin{array}{r}22984^{*} \\
56774 * \\
222814^{* *} \\
4327\end{array}$ \\
\hline Total & 24 & 1262216 & \\
\hline
\end{tabular}

The usual analysis of variance gives:

With equation (4.1) or (4.2) we can compute the expected values $\hat{y} j$ of $y$, which are given below.

\begin{tabular}{cccccc}
\hline & $\mathrm{A}$ & $\mathrm{B}$ & $\mathrm{C}$ & $\mathrm{D}$ & $\mathrm{E}$ \\
\hline $\begin{array}{c}\text { Expected } \\
\text { mean } \\
\text { values }\end{array}$ & 982.5 & 1386.6 & 1459.9 & 1473.2 & 1475.4 \\
\hline $\begin{array}{c}\text { Observed } \\
\text { mean } \\
\text { values }\end{array}$ & 984.0 & 1386.0 & 1458.0 & 1486.0 & 1464.0 \\
\hline
\end{tabular}


Now we can apply (3.1) and split the sum of squares attributed to treatments into two portions, as shown below.

\begin{tabular}{l|c|c|c}
\hline $\begin{array}{c}\text { Source of } \\
\text { variation }\end{array}$ & $\begin{array}{c}\text { Degrees of } \\
\text { freedom }\end{array}$ & $\begin{array}{c}\text { Sums of } \\
\text { squares }\end{array}$ & Mean square \\
\hline $\begin{array}{l}\text { Regression by } \\
\text { Mitscherlich's }\end{array}$ & 2 & 889756 & $444878 * *$ \\
\hline law & 2 & 1500 & 750 \\
\hline $\begin{array}{l}\text { Deviations } \\
\text { from } \\
\text { regression }\end{array}$ & 2 & & \\
\hline
\end{tabular}

The deviations from regression provide a new estimate for the residual variance. This estimate is not statistically different from the residual of the whole experiment. Therefore the applicability of the law in this case is proved.

The variances of $\alpha \quad \beta$ and $\varrho$ can be computed by Stevens' method. They are respectively

$$
\begin{gathered}
\mathrm{s}^{2}=2029, \mathrm{~s}^{2}=6227, \mathrm{~s}^{2}=0,02668 . \\
\beta \\
5-\text { THE APPLICABILITY OF THE LAW }
\end{gathered}
$$

There is much controversy on the general aplicability of Mitscherlich's law. It is undoubtedly true that in many cases the law cannot be applied, and that is the reason why think it is necessary to test the applicability in each case investigated.

In many cases where Mitscherlich's first aproach equation is not suitable, the second approach formula can be applied. But even in some cases, where there is no injurious effect of the fertilizer, both formulas are not adequate.

Even in cases where the yields fundamentally follow Mitscherlich's first approach formula, chance deviations from the expected values may cause a large experimental error and thus may not permit the fitting of the law to the data. This conclusion can be too mathematically demonstrated. 
Let us assume, for example, an experiment with three levels $\mathrm{x} 1, \mathrm{x} 2, \mathrm{x} 3$, with $\mathrm{x} 2-\mathrm{x} 1=\mathrm{x} 3-\mathrm{x} 2$. If the yields follow Mitscherlich's law, we must have for $i=1,2,3$ the expected values

$$
\hat{y} \mathbf{i}=A[1-10 \multimap(x i+h)]
$$

But, on the account of the experimental error, we have, instead of $\hat{y i}$, a stochastic variable yi with mean $\hat{y} i$ and variance $\sigma^{2}$.

In the case we are discussing we must have (3, pp. 11-13) when $\overline{\mathrm{yi}}(\mathrm{i}=1,2,3)$ is the observed mean of the $r$ replicates at the three levels,

$$
\begin{aligned}
& \overline{\mathrm{y}} 1<\overline{\mathrm{y}} 2<\overline{\mathrm{y}} 3, \\
& \overline{\mathrm{y} 3}<2 \mathrm{y} 2-\mathrm{y} 1 .
\end{aligned}
$$

On the account of (5.1) the probability of applicability of the law to the observed data is

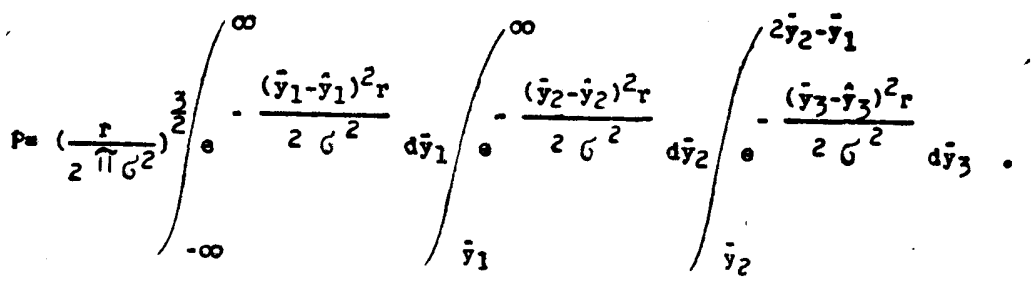

It is easy to show that we have $P<1$, that is, there is the possibility of the inapplicability of the law even when it is essencially suitable. Except in rare cases where the experimental error $\sigma$ should be extremely large, or the difference $\mathrm{x} 2-\mathrm{x} 1=\mathrm{x} 3-\mathrm{x} 2$ extremely small, $\mathrm{P}$ cannot approach the value zero. Taking any value between 0 and 1 , for instance 
$P=0.8$, this means that the law can be applied only in $80 \%$ cases tested. This possibility can be increased by the use of suitable designs, diminishing the experimental error, and keeping the difference $\mathrm{x} 2-\mathrm{x} 1=\mathrm{x} 3-\mathrm{x} 2$ sufficiently large to obtain a value of $\mathrm{P}$ as near 1 as possible, but not large enough to cause injurious effects from the fertilizers.

\section{6 - CONCLUSIONS}

Efficient estimates of the parameters of Mitscherlich's first approach law can be obtained by the method of least squares without too difficult computations. Sometimes the estimates obtained prove that the formula cannot be applied.

The analysis of variance and tests for the applicability of the formula can be associated.

Mitscherlich's equation may not be applicable to some cases, even when essentially correct, when chance variation affecting the data is too large.

The new methods give more prominence to Mitscherlich's law and allow its use in the analysis of variance of certain types of fertilizer experiments.

The computation of the variances of the parameter $\partial=10-c$ by Stevens' method gives a sound basis to the study of the constancy of $c$ in experiments with soil.

$$
7-\text { NOTE }
$$

We are grateful to Professor F. G. Brieger, who corrected this English translation, and to Dr. Raul Edgard Kalckmann, who supplied the experimental data.

\section{8 - BIBLIOGRAFIA (REFERENCES)}

1-KENDALL, Maurice G. (1948). "The Advanced Theory of Statistics", vol. II. London: Charles Griffin.

2-KLETSCHKOWSKY, W. M. and P. A. Shelesnow. (1931). "Ueber Verschiebungen der Wirkungsfaktoren von Sticks- 
toff und Phosphorsaure. Landwirtschafliche Jahrbücher, LXXIV, pp. 353-404.

3-PIMENTEL GOMES, Frederico e Eurípedes Malavolta. (1949). "Considerações Matemáticas sôbre a Lei de Mitscherlich". Piracicaba, Brasil.

4- PIMENTEL GOMES, Frederico e Eurípedes Malavolta. (1949). "Aspectos Matemáticos e Estatísticos da Lei de Mitscherlich". Anais da Escola Superior de Agricultura "Luiz de Queiroz", vol. 6, pp. 193-229. Piracicaba, Brasil.

5-PIMENTEL GOMES, Frederico. (1950). "A Lei de Mitscherlich e a Análise da Variância em Experiências de Adubação". Seminários de Estatística Aplicada ( $3^{\circ}$. série), pp. 115-127. Campinas, Brasil. 